
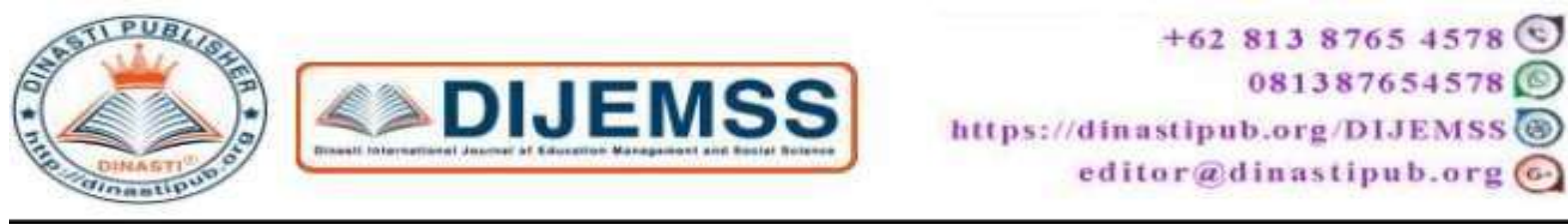

\title{
THE EFFECT OF COMPETENCE AND MOTIVATION ON ORGANIZATIONAL COMMITMENTS AND ITS IMPLICATIONS ON EMPLOYEE PERFORMANCE
}

\author{
Khoirul Anwar ${ }^{1}$, Muhammad Havidz Aima ${ }^{2}$ \\ ${ }^{1)}$ Magister of Management, Lecturer of Postgraduate, Mercu Buana University, Indonesia \\ ${ }^{2)}$ Magister of Management, Lecturer of Postgraduate, Mercu Buana University, Indonesia
}

\begin{tabular}{|c|c|}
\hline $\begin{array}{l}\text { ARTICLE INFORMATION } \\
\text { Received: } 25 \text { December } 2019 \\
\text { Revised: } 30 \text { December } 2019 \\
\text { Issued: } 1 \text { January } 2020 \\
\text { (filled in by Editor) } \\
\text { Corresponding author: first author } \\
\text { E-mail: } \\
\text { kho.anwar69@gmail.com; } \\
\text { havidz.aima@mercubuana.ac.id }\end{array}$ & $\begin{array}{l}\text { Abstract: The purpose of this study is to find out and } \\
\text { explain the effect of competence and motivation on } \\
\text { organizational commitment and its implications for } \\
\text { employee performance, which in this case is the } \\
\text { performance of the PBC Audit Functional Officer at the } \\
\text { Directorate General of Customs and Excise, Ministry of } \\
\text { Finance of the Republic of Indonesia. The research method } \\
\text { uses a quantitative approach, which became the population } \\
\text { in this study were } 318 \text { PBC Audit Functional Officers of the } \\
\text { Directorate General of Customs and Excise. The selection } \\
\text { of sample is done by simple random sampling technique } \\
\text { (Slovin 10\% error tolerance), so that } 77 \text { respondents are } \\
\text { determined. Data collection techniques that used are } \\
\text { interviews and questionnaire instruments. The questionnaire } \\
\text { survey instrument was randomly delivered to the PBC } \\
\text { Audit Functional Officer at the Directorate General of } \\
\text { Customs and Excise. The data is analyzed using structural } \\
\text { equation modeling (SEM) with the Smart PLS } 3.0 \text { software } \\
\text { program. This study revealed that competence, motivation } \\
\text { and commitment organizational had a significant positive } \\
\text { effect on employee performance, both partially and } \\
\text { simultaneously. Besides that, organizational commitment } \\
\text { variable does not mediate competence and motivation } \\
\text { variables on employee performance. }\end{array}$ \\
\hline & $\begin{array}{l}\text { Keywords: Competence, motivation, organizational } \\
\text { commitments, and employee performance }\end{array}$ \\
\hline
\end{tabular}

\section{INTRODUCTION}

With the enactment of the globalization era and free trade, competition between countries in the field of economy and trade between countries has become tighter. One of the applications of free trade today is the ASEAN Free Trade Area (AFTA) which is a form of agreement from ASEAN 
countries to establish a free trade area in order to improve economic competitiveness in the ASEAN region and has been started since December 2015.

The government has a role in encouraging and improving the national economy to be able to compete in global markets. In carrying out this role, the government must improve the ability and competence of human resources (HR) of Indonesia continuously to strive to be able to support and work professionally, so that it can win competition with other ASEAN countries. In addition, the government must also develop human resources (HR) that can work professionally and provide the best service to the community so that created better economic growth.

DJBC's contribution in encouraging the growth of national economy is expected to increase the ease of doing business in Indonesia, the smooth flow of trade between countries, and the ease of licensing in supporting industries related to supply chain activities of trade flows between countries. Other than that, DJBC's other contribution is to safeguard state finances through receiving import duties, export duties and excise. In carrying out this function, among others, it is carried out with audit activities in the field of customs which in this case is carried out by the Audit Customs and Excise Functional Officer.

The Civil Servants Law was drafted to make them work as professionals in the government effectively and efficiently and provide quality services to the community. In order to create professional employees, DJBC is faced with problems including considerations in the placement of officials according to occupational competency standards, patterns of career development that do not yet exist and the implementation of education and training programs that are not yet fully in line with the objectives. DJBC is demanded to be a professional, credible, transparent and accountable of fiscal manager. To realize that, DJBC must be supported by employees who have high performance. The performance of PBC Audit functional officials can be seen from the ability to complete work, in this case the completion of work is given a credit score and from the quality of work completion based on established standards.

Based on data sources in the field, it is known that the percentage of PBC Audit credit figures that were not achieved was quite large with an average annual rate of $41.5 \%$, even in the second semester of 2017, there was a significant increase to 63 percent. Though the achievement of the credit score is a benchmark performance of functional officials. Meanwhile the results of evaluating the completion of the audit report from 2017 to 2018 can be seen the majority of employees in completing the audit report is not according to the standard. There are still many employees who complete the audit report more than 90 days. This illustrates that there are still problems with employee performance in this case not being able to complete the audit report on time.

These things indicate that there is still a need for improvement to be done by PBC Audit Functional Officers of the Directorate General of Customs and Excise to achieve better employee performance.

\section{LITERATURE REVIEW}

\section{A. Competence}

Competence is an individual characteristic that underlies a person's performance or behavior at office. According to Muhammad Busro (2018: 26), competence is everything whose a person has in the term of knowledges, skills and other internal factors of an individual to be able to do a job based on their knowledges and skills. Thus, competence shows the skills or knowledge is detailed by professionalism in a particular field as something that is most important, as superior in that field.

According to Spencer \& Spencer (Muhammad Busro 2018: 26), competence is an underlying characteristic of a person that related to the effectiveness of individual performance in his work or basic characteristics of individuals who have a causal relationship with the criteria used as an effective reference or excellent performance in the workplace.

While Michael Zwell (2007:5) provides five competency categories consisting of:

1. Task achievement is a competency category related to good performance.

2. Relationship is a competency category that relates to communication and works well with others and satisfies their needs. 
3. Personal attribute is an individual's intrinsic competence and connects how people think, feel, learn and develop

4. Managerial is a competency specifically related to managing, supervising and developing people.

5. Leadership is a competency related to leading an organization and people to achieve the goals, vision, and goals of the organization

\section{B. Motivation}

Muhammad Busro (2018: 51) defines motivation as the mobilizer from within individuals to carry out certain activities in achieving goals. By providing the right motivation, employees will be encouraged to do everything possible in carrying out their duties.

Buhler, (in Ihsanuddin, 2016: 11) gives an opinion about the importance of motivation as follows: "Motivation is basically a process that determines how much effort will be devoted to carrying out work".

David McCleland in 1961 in his book entitled "The Achieving Society" said that human motivation is classified into 3 (three) main needs, namely:

1. Need for Achievement (n-Ach) is the human desire to do something better than before.

2. Need for Power (n-Pow) is the need to be stronger, more influential on others.

3. Need for affiliation (n-Aff) is the need to like, develop, or maintain friendships with others.

\section{Organizational Commitment}

Organizational commitment is one aspect that affects employee behavior in organizing. Allen and Mayer (in Mekta, 2017) stated that organizational commitment is a psychological construct that is characteristic of the relationship of organizational members with their organizations and has implications for individual decisions to continue membership in organization. Members who have a commitment to the organization will be more able to survive as part of the organization. According to Robbins and Judge (Honowati, 2016) states that commitment is a condition where an employee sides with a particular organization and its goals and intends to maintain membership in that organization.

\section{Employee Performance}

Muhammad Busro (2018: 87) said that performance is a performance both quantity and quality achieved by a person during a certain period, usually within one year.

Dessler (2011: 41) stated that performance is work performance, which is a comparison between work results and established standards. Whereas Mathis and Jackson (2001: 65) stated Performance is what employees do or don't do. (Muhammad Busro, 2018: 89)

Based on this understanding it can be concluded that performance is the result of someone's work in an organization where its success can be assessed through the timeliness of completion of work, the amount of work completed (quantity) and the quality of work results.

\section{E. Framework}

The results of previous studies by Ari Setiadi et al. (2016) and Fakhrul Rozi (2017) show that competence has a positive effect on organizational commitment. Research is conducted by Ahmed Bin Ali Said et al. (2017), the results of the study suggest that there is a significant influence between motivation on organizational commitment. While research 
conducted by Fakhrul Rozi (2017), Murgianto et al. (2016) and Wahyu Yulianto (2017) gave results that competence has a positive and significant impact on employee performance. The results of research conducted by Randy and Aima (2019), Aprilynn Clarissa (2018), Ramona Octaviannand (2017), Ahmed bin Ali Said et al. (2017), all of them showed a significant influence between motivation on employee performance. While research conducted by Aprilynn Clarissa (2018), Ahmed bin Ali Said et al. (2017), Fakhrul Rozi (2017) all show that organizational commitment influences employee performance.

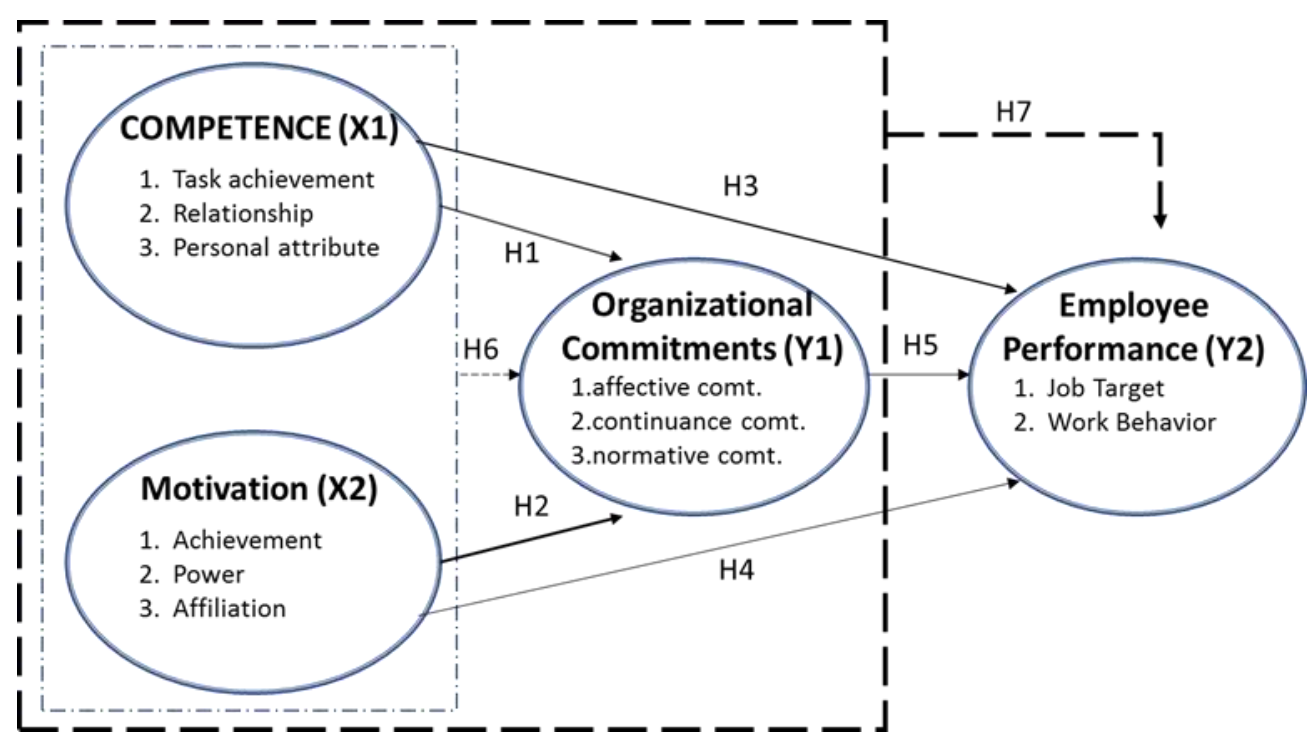

Figure 1. Framework

\section{RESEARCH METHODS}

This research is a type of descriptive statistical research using survey methods and is designed with the aim to be able to understand, explain and analyze the correlation between independent variables to the dependent variable which in the study will be analyzed using relevant statistical analysis to test hypotheses. As independent variables in this study are competence (X1) and motivation (X2), while the dependent variable is organizational commitment (Y1) and employee performance (Y2). The following is an operational definition of the variables used in this study:

Table 1. Variable Measurement $(\mathrm{X} 1, \mathrm{X} 2)$

\begin{tabular}{|c|c|c|c|}
\hline Variable & Dimension & Indicator & $\begin{array}{l}\text { No. } \\
\text { Item }\end{array}$ \\
\hline \multirow{8}{*}{$\begin{array}{l}\text { Competence (X1) } \\
\text { Michaell Zwell (2007) }\end{array}$} & 1) Task achievement & a) orientation to results & 1 \\
\hline & & b) innovation & 2 \\
\hline & & c) care about quality & 3 \\
\hline & & $\begin{array}{l}\text { d) continuous } \\
\text { improvement }\end{array}$ & 4 \\
\hline & & e) technical expertise & 5 \\
\hline & 2) Relationship & a) cooperation & 6 \\
\hline & & b) service orientation & 7 \\
\hline & & c) build relationships & 8 \\
\hline
\end{tabular}




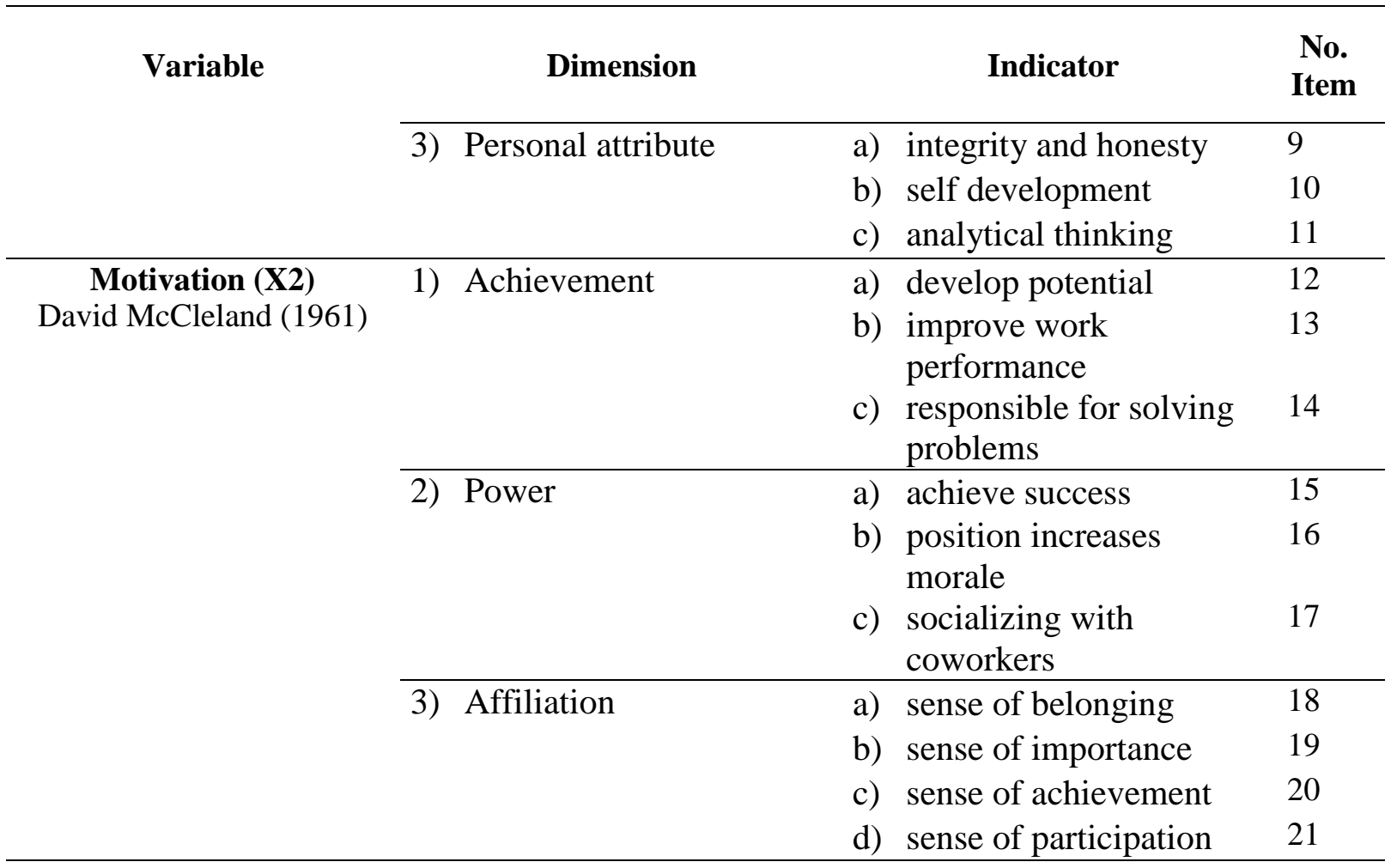

Table 2. Variable Measurement (Y1, Y2)

Variable

Dimension

Indicator

Item

Number

\section{Organizational Commitment (Y1)}

Alen and Mayer (1993)
1) affective commitment

a) Emotional

b) Identification

c) Employee involvement in the organization
2) continuance commitment

a) Losses when leaving the organization

b) Employees need organization

3) normative

a) Social Reward

b) Organizational reward

commitment

27

22

23

24

25

26

28

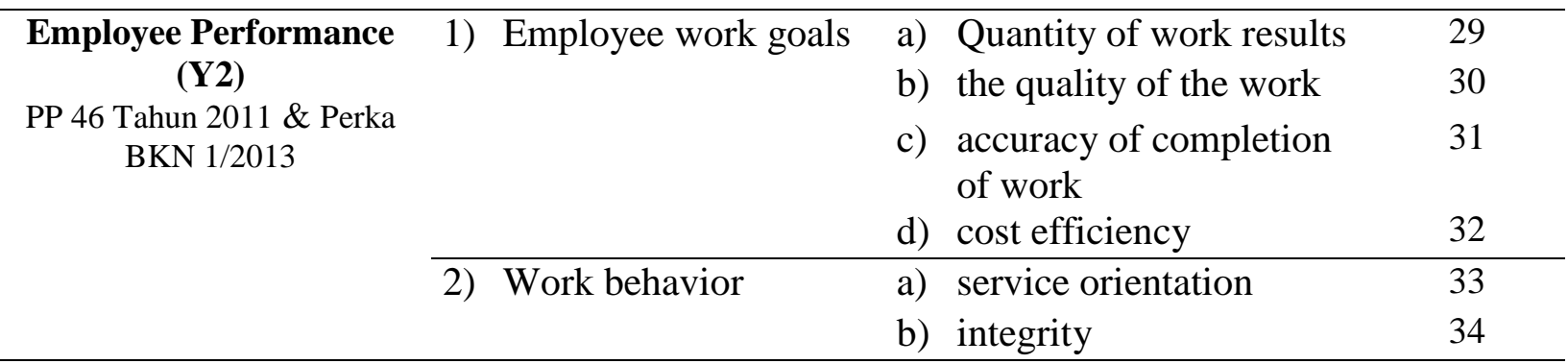




$\begin{array}{ll}\text { c) commitment } & 35 \\ \text { d) discipline } & 36 \\ \text { e) cooperation } & 37\end{array}$

\section{Population and sample}

The population is determined and restricted to PBC Auditor Functional Officers in the DJBC environment, amounting to 318 (three hundred eighteen) people based on staffing data in October 2018. In this study the author uses the Slovin formula.This study uses a percentage of leeway of $10 \%$, so as to establish a research sample with the Slovin formula, with the following calculation:

$$
\begin{aligned}
& n=\frac{318}{1+318(0,1)^{2}} \\
& \quad n=76,07656 \text { set to } 77
\end{aligned}
$$

From the calculation, a total sample of 77 respondents was obtained

\section{Method of Analysis}

This research uses Partial Least Square (PLS) analysis technique, a variant-based Structural Equation Model (SEM) analysis that can simultaneously test measurement models as well as structural model testing using help of SmartPLS software.

\section{FINDINGS AND DISCUSSION}

This research was conducted through 2 (two) test models, namely the evaluation of the measurement model (outer model) and the evaluation of the structural model (inner model).

\section{Evaluation of measurement models (outer models)}

Evaluation of the measurement model is carried out to determine validity and reliability that connects the indicator with its latent variable. This evaluation includes testing of convergent validity and discriminant validity testing. For testing the validity, the results of the calculation of the measurement model with SEM PLS version 3.0 with the loading factor value used in this study is > 0.5. The results of factor loading values for variable indicators in this study can be seen in Figure 2. 


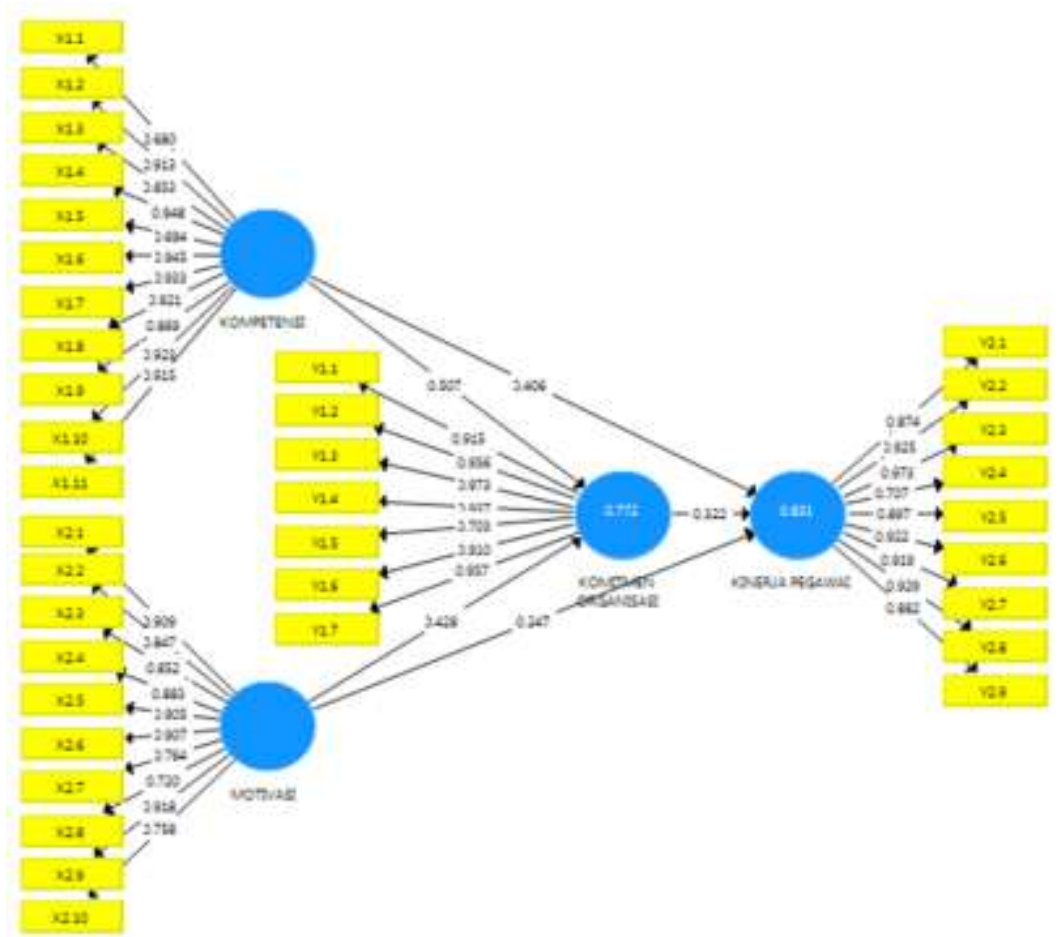

Figure. 2 Outer Model Results

Based on Figure 2, it can be seen that the indicators of these variables with a loading factor value $>0.5$ are valid and can be used. Next it is done by looking at the value of Average Variance Extracted (AVE). AVE value is said to be good if it has a value greater than 0.5 . The results of research on the AVE value can be seen in Table 5

Table 3. Value of Average Variance Extracted (AVE) Variable

\begin{tabular}{lc}
\hline \multicolumn{1}{c}{ Variable } & $\begin{array}{c}\text { Average Variance Extracted } \\
\text { (AVE) }\end{array}$ \\
\hline Competence & $\mathbf{0 . 7 4 9}$ \\
Motivation & $\mathbf{0 . 6 8 1}$ \\
Organizational & $\mathbf{0 . 8 0 5}$ \\
Commitment & \\
Employee Performance & $\mathbf{0 . 7 7 7}$ \\
\hline
\end{tabular}

It can be seen that the AVE value of all research variables has a value $>0.5$, which means that the manifest variable representation of the latent construct is quite good. The construct reliability test is done by looking at the value of composite reliability which is stated as reliable value $>0.7$. And see the value of Cronbach's alpha which is declared reliable if the value is $>0.6$. The output from the outer model can be seen in Table 3 .

Table 4. Cronbach's Coefficient Alpha and Composite Reability (CR) Value

\begin{tabular}{lcc}
\hline \multicolumn{1}{c}{ Variable } & $\begin{array}{c}\text { Cronbach's Coefficient } \\
\text { Alpha }\end{array}$ & $\begin{array}{c}\text { Composite Reability } \\
\text { (CR) }\end{array}$ \\
\hline Competence & $\mathbf{0 . 9 6 9}$ & $\mathbf{0 . 9 7 0}$ \\
Motivation & $\mathbf{0 . 9 5 6}$ & $\mathbf{0 . 9 5 4}$ \\
Organizational & $\mathbf{0 . 9 6 4}$ & $\mathbf{0 . 9 6 6}$
\end{tabular}


Commitment

Employee Performance

As per Table 4 it is known that the Cronbach's Coefficient Alpha value >0.6 and Composite Reliability (CR) value $>0.7$ so that all variables are declared reliable and it can be concluded that the research model has met the composite reliability.

\section{Evaluation of structural models (inner model)}

This evaluation is done by evaluating the value of the path coefficient (path coefficient), the value of R2, effect size f2, Goodness of Fit Index (GoF), and predictive relevance (Q2).

Evaluation of the value of the path coefficient can be seen in Table 5.

Table 5. The Effect of Partial Variables

\begin{tabular}{lccc}
\hline & $\begin{array}{c}\text { Original } \\
\text { Sample }(\mathbf{O})\end{array}$ & $\begin{array}{c}\text { T Statistic } \\
(\text { O/STDEV }\end{array}$ & $\begin{array}{c}\text { P } \\
\text { Values }\end{array}$ \\
\hline Competence $(\mathrm{X} 1) \rightarrow$ Org. Commitment (Y1) & $\mathbf{0 . 5 0 7}$ & $\mathbf{6 . 4 2 4}$ & $\mathbf{0 . 0 0 0}$ \\
Competence (X1) $\rightarrow$ Emp. Performance (Y2) & $\mathbf{0 . 4 0 6}$ & $\mathbf{3 . 8 9 5}$ & $\mathbf{0 . 0 0 0}$ \\
Motivation (X2) $\rightarrow$ Org. Commitment (Y1) & $\mathbf{0 . 4 2 8}$ & $\mathbf{5 . 0 0 2}$ & $\mathbf{0 . 0 0 0}$ \\
Motivation (X2) $\rightarrow$ Emp. Performance (Y2) & $\mathbf{0 . 2 4 7}$ & $\mathbf{2 . 4 6 4}$ & $\mathbf{0 . 0 1 4}$ \\
Org. Commitment (Y1) $\rightarrow$ Emp. Performance & $\mathbf{0 . 3 2 2}$ & $\mathbf{2 . 7 9 6}$ & $\mathbf{0 . 0 0 5}$ \\
(Y2) & & & \\
\hline
\end{tabular}

Based on Figure 2 and Table 5, the structural equation of the study is 1.) Organizational Commitment $(\mathrm{Y} 1)=0.507 \gamma 1+0.428 \gamma 2$, and 2.) Employee Performance $(\mathrm{Y} 2)=0.406 \gamma 3+0.247 \gamma 4+0.322 \beta$ From this equation can be concluded as follows:

Competence has an effect of 0.507 on Organizational Commitment with a T-Statistic value of 6,424 and P-Values of 0,000 .

Competence has an effect of 0.406 on employee performance with a T-Statistic value of 3,895 and PValues of 0,000 .

Motivation has an effect of 0.428 on organizational commitment with a T-Statistic value of 5.002 and P-Values of 0.000 .

Motivation has an effect of 0.247 on employee performance with a T-Statistic value of 2.464 and PValues of 0.014 .

Organizational commitment has an effect of 0.322 on employee performance with a T-Statistic value of 2.796 and P-Values of 0.005 .

Evaluate the value of $\mathbf{R 2}$. The results showed the values of R-squares 0.722 and 0.831 can be concluded that the structural model is very good. This value means that $72.2 \%$ of organizational commitment variables (Y1) can be influenced by competency variables (X1) and motivation variables (X2) and $83.1 \%$ employee performance variables (Y2) can be influenced by competency variables (X1) and motivation variables (X2) and organizational commitment variable (Y1).

While the calculated R2 and F values can be seen from the following calculations:

\begin{tabular}{|l|l|l}
\hline $\begin{array}{l}\mathrm{R}^{2}=0,722(\mathrm{OC}) \\
\text { F statistic }=\frac{\frac{R^{2}}{(k-1)}}{1-R^{2} /(n-k)}\end{array}$ & $\begin{array}{l}\mathrm{R}^{2}=0,831(\mathrm{EP}) \\
\text { F statistic }=\frac{\frac{0.772}{(4-1)}}{1-0,772 /(77-4)} \\
\text { F statistic }=0.257 / 0.0031 \\
\text { F statistic }=82.39\end{array}$ \\
\hline \hline
\end{tabular}


The calculated $F$ value in this study is 82.39 and 119.65 the $F$ table value on alpha 0.1 is 2.16 . It can be seen that $f$ arithmetic $>f$ Table (2.16). The results of the effect size (f square) value with Smart PLS version 3.0 can be seen in Table 6.

Table. 6 The results of the effect size value $\mathrm{f}^{2}$

\begin{tabular}{lcc}
\hline \multicolumn{1}{c}{ Variable } & Value f2 & Information \\
\hline Competence $(\mathrm{X} 1) \rightarrow$ Org. Commitment (Y1) & $\mathbf{0 . 4 7 2}$ & strong \\
Motivation (X2) $\rightarrow$ Org. Commitment (Y1) & $\mathbf{0 . 3 3 6}$ & strong \\
Competence (X1) $\rightarrow$ Emp. Performance (Y2) & $\mathbf{0 . 2 7 8}$ & moderate \\
Motivation (X2) $\rightarrow$ Emp. Performance (Y2) & $\mathbf{0 . 1 1 3}$ & weak \\
Org. Commitment (Y1) $\rightarrow$ Emp. Performance & $\mathbf{0 . 1 4 0}$ & weak \\
(Y2) & & \\
\hline
\end{tabular}

Goodness of Fit Index (GoF) test results:

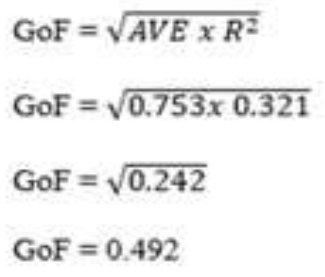

$\mathrm{AVE}=(0.749+0.681+0.805+0.777) / 4=0.753$

$R$ square $=(0.772 \times 0.831) / 2=0.321$

Based on these results it can be concluded that the combined performance of the measurement model (outer model) and structural model (inner model) as a whole is quite good because the Goodness of Fit Index (GoF) value is more than 0.36 (large scale GoF).

Predictive Relevance Testing (Q2)

$$
\begin{array}{ll}
\mathrm{Q} 2=1-\left(1-\mathrm{R} 1^{2}\right)\left(1-\mathrm{R} 2^{2}\right) & \\
\mathrm{Q} 2=1-(1-0.772)(1-0.831) & \mathrm{Q} 2=1-0.0385 \\
\mathrm{Q} 2=1-(0.228)(0.169) & \mathrm{Q} 2=0.962
\end{array}
$$

Based on the above calculation it can be concluded that this model has a good predictive relevance because the value of $\mathrm{Q} 2=0.962$ is greater than 0 meaning that the endogenous latent variable has a predictive relevance (Q2) value greater than 0 (zero) so that the exogenous latent variable is able to predict its endogenous variable namely employee performance.

Table 7. The Effects of Simultaneous Variables

\begin{tabular}{lccccc}
\hline & & $\mathbf{R}$ & $\mathbf{F}$ & $\mathbf{F}$ & Conclusion \\
& & square & statistic & table & \\
\hline $\begin{array}{l}\text { (Competence, Motivation) } \\
\text { Commitment }\end{array}$ & Org. & $\mathbf{0 . 7 7 2}$ & $\mathbf{8 2 . 3 9}$ & $\mathbf{2 . 1 6}$ & $\begin{array}{c}\text { F statistic }>\text { F } \\
\text { table } \\
\text { (H6 accepted) }\end{array}$ \\
\hline $\begin{array}{l}\text { (Competence, } \\
\text { Commitment }\end{array}$ & & & & $\begin{array}{c}\text { Motivation, } \\
\text { Performance }\end{array}$ \\
\hline
\end{tabular}


Tabel 8. Indirect Effect of Variable Independent on Dependent Variables

\begin{tabular}{lccc}
\hline & $\begin{array}{c}\text { Original } \\
\text { Sample (O) }\end{array}$ & $\begin{array}{c}\text { T Statistic } \\
(\text { O/STDEV) }\end{array}$ & $\begin{array}{c}\text { P } \\
\text { Values }\end{array}$ \\
\hline $\begin{array}{l}\text { Competence } \rightarrow \text { Org. Commitment } \\
\rightarrow \text { Emp. Performance }\end{array}$ & 0.163 & 2.583 & 0.010 \\
\hline $\begin{array}{l}\text { Motivation } \rightarrow \text { Org. Commitment } \\
\rightarrow \text { Emp. Performance }\end{array}$ & 0.138 & 2.461 & 0.014 \\
\hline
\end{tabular}

The results of testing the hypothesis in this study are as follows: (1) Competence has a significant positive effect on organizational commitment, the path coefficient value is 0.507 and $t$ arithmetic $6.424>\mathrm{t}$ Table 1.229, $\mathrm{p}$ is $0.000<0.1$, then $\mathrm{H} 1$ is accepted and $\mathrm{H} 0$ is rejected; (2) Motivation has a significant positive effect on organizational commitment, path coefficient values are 0.428 and $t$ arithmetic $5.002>\mathrm{t}$ Table 1.229 with a p value of $0.000<0.1$, then $\mathrm{H} 2$ is accepted and $\mathrm{H} 0$ is rejected; (3) Competence has a significant positive effect on employee performance, the path coefficient value is 0.408 and $t$ arithmetic (3.895) $>\mathrm{t}$ Table (1.293) with $\mathrm{p}$ of $0.000<0.1$, thus $\mathrm{H} 3$ is accepted and $\mathrm{H} 0$ is rejected; (4) Motivation has a significant positive effect on employee performance, the path coefficient value is 0.247 and $\mathrm{t}$ arithmetic $(2,464)>\mathrm{t}$ Table $(1,293)$ with $\mathrm{p}$ of $0.014<0.1$, then $\mathrm{H} 4$ is accepted and H0 is rejected; (5) Organizational commitment significantly positive effect on employee performance, the value of the path coefficient of 0.322 and $t$ arithmetic (2.796) $>t$ Table (1.293) with $\mathrm{p}$ of 0.005 , thus H5 is accepted $(\mathrm{p}<0.1)$ and H0 is rejected, (6) Competence and Motivation have a significant positive effect on organizational commitment, value (R2) is 0.772 with a statistical value of 82.39 > f-Table (2.16), then H6 is accepted and H0 is rejected; (7) Competence, Motivation, Organizational commitment have a significant positive effect on employee performance, R2 value is 0.831 with a statistical value of 119.65> fTable (2.16), then $\mathrm{H} 7$ is accepted and H0 is rejected; (8) Organizational commitment does not mediate Competence on Employee Performance, direct effect $0.165>$ indirect effect 0.163 and $t$ statistik $(3.895)>t$ Table $(1,293)$ with $\mathrm{p}$ of 0,000 then $\mathrm{H} 8$ is rejected and $\mathrm{H} 0$ is accepted; (9) Organizational commitment mediates Competence and Motivation on Employee Performance, direct effect 0.061 < indirect effect 0.138 and t statustik $(2,464)>t$ Table $(1,293)$ with $\mathrm{p}$ of 0.014 then $\mathrm{H} 9$ is accepted and $\mathrm{H} 0$ is rejected.

Table 9. Correlation Variable Dimensions Matrix

\begin{tabular}{|c|l|c|c|c|c|c|}
\hline \multirow{2}{*}{ Variable } & \multicolumn{1}{|c|}{ Dimention } & \multicolumn{2}{|c|}{ Organizational Commitment } & \multicolumn{2}{c|}{$\begin{array}{c}\text { Employee } \\
\text { Performance (Y2) }\end{array}$} \\
\cline { 2 - 7 } & & Y1.1 & Y1.2 & Y1.3 & Y2.1 & Y2.2 \\
\hline \multirow{2}{*}{$\begin{array}{c}\text { Competenc } \\
\text { e (X1) }\end{array}$} & $\begin{array}{l}\text { Task } \\
\text { achievement }\end{array}$ & $\mathbf{- 0 . 1 8 1}$ & $\mathbf{- 0 . 2 4 9}$ & $\mathbf{0 . 1 2 5}$ & $\mathbf{- 0 . 2 5 9}$ & $\mathbf{- 0 . 3 3 2}$ \\
\cline { 2 - 7 } & Relationship & $\mathbf{0 . 6 6 3}$ & $\mathbf{0 . 2 4 7}$ & $\mathbf{0 . 3 0 9}$ & $\mathbf{0 . 4 5 8}$ & $\mathbf{0 . 4 8 0}$ \\
\cline { 2 - 7 } & $\begin{array}{l}\text { Personal } \\
\text { attribute }\end{array}$ & $\mathbf{0 . 0 0 3}$ & $\mathbf{0 . 2 4 9}$ & $\mathbf{- 0 . 0 5 4}$ & $\mathbf{0 . 3 1 1}$ & $\mathbf{0 . 3 7 4}$ \\
\hline \multirow{3}{*}{$\begin{array}{c}\text { Motivation } \\
\text { (X2) }\end{array}$} & Achievement & $\mathbf{- 0 . 2 3 4}$ & $\mathbf{0 . 0 3 5}$ & $\mathbf{- 0 . 4 0 0}$ & $\mathbf{0 . 0 7 8}$ & $\mathbf{- 0 . 0 6 7}$ \\
\cline { 2 - 7 } & Power & $\mathbf{0 . 1 0 8}$ & $\mathbf{- 0 . 2 1 0}$ & $\mathbf{0 . 2 7 8}$ & $\mathbf{0 . 0 3 0}$ & $\mathbf{0 . 0 9 9}$ \\
\cline { 2 - 7 } & Affiliation & $\mathbf{0 . 5 7 6}$ & $\mathbf{0 . 8 6 3}$ & $\mathbf{0 . 5 5 9}$ & $\mathbf{0 . 3 9 6}$ & $\mathbf{0 . 4 4 3}$ \\
\hline
\end{tabular}


Table 10. Dimensional Correlation Matrix of Endogenous Variables

\begin{tabular}{|c|c|c|c|}
\hline \multirow{2}{*}{ Variable } & \multirow[t]{2}{*}{ Dimention } & \multicolumn{2}{|c|}{$\begin{array}{c}\text { Employee Performance } \\
\text { (Y2) }\end{array}$} \\
\hline & & Y2.1 & Y 2.2 \\
\hline \multirow{3}{*}{$\begin{array}{c}\text { Organizational } \\
\text { Commitment (Y1) }\end{array}$} & affective commitment & 0.391 & 0.684 \\
\hline & continuance commitment & 0.306 & 0.224 \\
\hline & normative commitment & 0.184 & 0.015 \\
\hline
\end{tabular}

\section{Correlation Analysis Between Dimensions}

From Table 9 and Table 10 above it can be concluded as follows:

1. On the variable of competence to the variable organizational commitment, the highest correlation dimension is the relationship to the dimensions of affective commitment that is equal to 0.663 .

2. On the competency variable on employee performance variables, the highest correlation dimension is the relationship dimension to the dimensions of work behavior, which is equal to 0.480 .

3. On the motivation variable on organizational commitment variable, the highest correlation dimension is the influence of the affiliation dimension on the dimension of ongoing commitment, amounting to 0.863 .

4. On the motivation variable on employee performance variables, the highest correlation dimension is the affiliation dimension to the dimensions of work behavior, amounting to 0.443 .

5. On the variable organizational commitment to employee performance variables, the highest correlation dimension is the dimension of affective commitment to the dimensions of work behavior, amounting to 0.684 .

\section{Effect of Competence on Organizational Commitment (H1)}

The results of the study indicate that competence has a positive and significant effect on organizational commitment. These results are consistent with previous research conducted by Ari Setiadi et al. (2016) and Fakhrul Rozi (2017).

Based on the correlation between dimensions of the variables produced the relationship dimension has the strongest influence on organizational commitment. This relationship dimension competency includes; cooperation, service orientation, interpersonal care, organizational intelligence, building relationships, conflict resolution, attention to communication and cross-cultural sensitivity. Management can make the relationship dimension a major competency that must be developed to increase organizational commitment.

Effect of Motivational Effects on Organizational Commitment (H2)

The results showed that motivation had a positive and significant effect on organizational commitment. these results are consistent with the results of research conducted by Ahmed Bin Ali Said et al. (2017). Based on the correlation between the dimensions of the variables produced dimensions of affiliation has the strongest influence on employee commitment.

The need for affiliation (need for affiliation) is the need to like, develop, or maintain friendships with others. In line with this, organizational management should pay attention to the relationship between the organization's acceptance of employees and good relations between employees.

\section{Effect of Motivation on Employee Performance (H4)}

The results showed that motivation had a positive and significant effect on employee performance. these results are consistent with the results of research conducted by Randy and Aima (2019), Aprilynn Clarissa (2018), Ramona Octaviannand (2017), Ahmed bin Ali Said et al. (2017). Based on the correlation between the dimensions of the variables produced affiliation dimensions have the most powerful influence on employee performance. This shows that the DJBC agency needs to excel and 
the need for employee self-actualization is better. Employees need a more conducive relationship atmosphere between employees.

Therefore DJBC leaders need to pay attention to meeting the needs in terms of building relationships between employees.

Effect of Organizational Commitment on Employee Performance (H5)

The results showed organizational commitment had a positive and significant effect on employee performance. these results are consistent with the results of research conducted by Aprilynn Clarissa (2018) and Ahmed bin Ali Said et al. (2017). Based on the correlation between dimensions of variables produced dimensions of affective commitment have the strongest influence on employee performance. Affective commitment is an attachment to the organization on the basis of emotional ties not because of high salaries or moral ties for certain reasons. The indicator is that employees want to be part of the organization because of emotional ties or feel they have the same values as the organization. Leaders grow affective commitment through the internalization of the organization's vision and mission continuously.

\section{Effect of Competence and Motivation on Organizational Commitment (H6)}

The results showed that competence and motivation had a positive and significant effect on organizational commitment. This influence can be seen from the R2 value of 0.772 which means that organizational commitment is influenced by the competence and motivation of $77.2 \%$, the rest is influenced by other variables. These results are consistent with the assumption that there is a link between competency and motivation variables jointly (simultaneously) on organizational commitment.

\section{Effect of Competence, Motivation, and Organizational Commitment on Employee Performance} (H7)

The results showed competency, motivation and organizational commitment had a positive and significant effect on employee performance. This influence can be seen from the R2 value of 0.831 , which means that employee performance is influenced by the competence, motivation and organizational commitment of $83.1 \%$ and the rest is influenced by other variables.

These results are consistent with the assumption that there is a link between variables of competency, motivation and organizational commitment together (simultaneously) on employee performance.

\section{Organizational Commitment Mediates Competence in Employee Performance (H8)}

The results show that organizational commitment does not mediate competence on employee performance. That is because the direct effect of competence on employee performance is greater when compared to its indirect effect. The research results are not in accordance with the results of research conducted by Fakhrul Rozi (2017).

\section{Organizational Commitment Mediates Motivation Toward Employee Performance (H9)}

The results show that organizational commitment mediates motivation on employee performance. That is because the direct effect of competence on employee performance is smaller when compared to its indirect effect. The results of the study are in accordance with the results of research conducted by Agustina Rasentalu et al. (2017).

Based on the research results above, it can be seen that the effect of competence on employee performance is more significant than the effect of motivation on employee performance. This is indicated by the value of the competency loading factor which is higher than motivation, besides the effect of competence on employee performance without the need to mediate by organizational commitment. DJBC needs to make the strategy to improve employee competency more emphasized than to increase motivation in achieving the best performance. Although an increase in employee motivation is still needed. 


\section{CONCLUSION AND SUGGESTION Conclusion}

Based on the results of the research and discussion above, the following conclusions: (1) Competence has a significant positive effect on organizational commitment, with the relationship dimension being the strongest influence. (2) Motivation has a significant positive effect on organizational commitment, with the dimensions of affiliation having the strongest influence. (3) Competence has a significant positive effect on employee performance, with the relationship dimension being the strongest influence. (4) Motivation has a significant positive effect on employee performance, with the affiliate dimension being the strongest influence. (5) Organizational commitment as a mediator in this study has a significant effect on employee performance, with the most influential dimensions of affective commitment. (6) Competence and motivation together have a significant positive effect on organizational commitment. (7) Competency, motivation and organizational commitment simultaneously have a positive and significant impact on employee performance. (8) Organizational commitment does not mediate competence on employee performance. (9) Organizational commitment mediates motivation on employee performance.

\section{Suggestions for DJBC Agencies}

In the competency variable it is found that the relationship dimension is the biggest and the most significant influence on organizational commitment and employee performance. This shows that employee competencies related to communication and working well with others have a strong influence in increasing employee organizational commitment and performance. DJBC's leadership in conducting competency development programs emphasizes enhancing collaboration, service orientation, interpersonal care, organizational intelligence, building relationships, conflict resolution, attention to communication and cross-cultural sensitivity. Activities that can be carried out include: Capacity Building, FGD, Workshop, Workshop.

In the motivation variable it was found that the dimensions of affiliation had the highest influence on the variables of organizational commitment and employee performance. the need for affiliation is the need to like, develop, or maintain friendships with others. DJBC must create a work environment that can establish excellent relationships and cooperation. Forms of activities that can be done among other things: assignments to different Teams, more intense interaction between superiors and subordinates and more flexible education through informal meetings, outbound activities involving all employees.

In the correlation of organizational commitment variables produced the highest dimensions of affective commitment have a positive effect on employee performance variables. This means that the organizational commitment improvement program to achieve the best performance carried out by DJBC must be in the form of activities that can foster attachment to the organization on the basis of emotional ties. The indicator is that employees want to be part of the organization because of emotional ties or feel they have the same values as the organization. Activities that can be carried out include: internalizing the Ministry of Finance's values, strengthening the application of the Basic Attitudes of the DJBC Employees, establishing role models, Coaching and Mentoring by superiors to subordinates.

\section{Suggestions for Future Researchers}

The author hopes that further research can take different research objects from functional officials within the DJBC environment and dig deeper into the variables that affect employee performance with a wider range of samples. The results found in the form of organizational commitment does not mediate employee performance opens up the possibility of the influence of other variables as a mediator that can affect employee performance. 


\section{REFERENCE}

Almusaddar, Ayman A. S, Sara Ravan Ramzan, Valliappan Raja. (2018). The Influence of Knowledge, Satisfication, and Motivation on Employee Performance Through Competence. International Journal of Business and General Management. Vol. 7. Issue 5.

Busro, Muhammad. (2018). Teori-teori Manajemen Sumber Daya Manusia. Kencana. Jakarta.

Hairuddin, Arminas, dkk. (2017). Motivation, Competence and Organizational Commitment's Effect on Lecturers' Job Satisfication and Lecturers Performance. International Jurnal of Management \& Social Sciences. Vo. 06. Issue. 03.

Hidayah, Tamriatin, Diana Sulianti K. Tobing. (2018). The Influence of Job Satisfication. Motivation, and Organizational Commitment to Employee Performance. International Journal of Scientific and Technology Research. Vol. 7. Issue 7.

Martini, Ida Ayu Oka, dkk. (2018). The Influence of Competency on Employee Performance through Organizational Commitment Dimension. IOSR Journal of Business and Management. Vol. 20. Issue 2.

Matriadi, Faisal, Ritha F. Dalimunthe. (2017). Analyzing the Compensation and Competence on Senior High Schools Teacher's Performance through the Mediating Role of Job Motivation. Advantaces in Economics, Business and Management Research. Vol. 46.

Murgianto, Siti Sulasmi, Suhermin. (2016). The Effect of Commitment, Competence, Work Satisfication on Motivation, and Performance of Employees at Integrated Service Office $f$ East Java. International Journal of Advanced Research Vo. 3, Issue-378-396.

Octaviannand, Ramona, Nurmala K. Pandjaitan, Sadikin Kuswanto. (2017). Effect of Job Satisfication and Motivation towards Employee's Performance in XYZ Shipping Company. Journal of Education and Practice. Vol. 8 No. 8.

Qatmeemalmarhoon, Ahmed bin Ali Said, dkk. (2017). Effect of Motivation on Employees' Performance and Employees' Commitment. International Journal of Management and Applied Science. Vol. 3, Issue-9.

Pranaputra, Randy Dwi, M. Havidz Aima (2019). The Effect of Workload and Compensation on Motivation and the Implication on Employee Performance of Directorate General of Postal Devices and Resource and Informatics Ministry of Communication and Informatics Republic of Indonesia. International Journal of Innovative Science and Research Technology. Volume 4, Issue 2

Renyut, Bernard C, dkk (2017). The Effect of Organizational Commitment, Competence on Job Satisfication and Employees Performance in Maluku Governor's Office. IOSR Journal of Business and Management. Vol. 19. Issue 11.

Sekaran, Uma dan Bougie, R. 2017. Metode Penelitian untuk Bisnis Pendekatan PengembanganKeahlian. Jakarta. Salemba Empat.

Setiadi, Ari, Endah Winarti HS, M Taufiq. (2016). Analisis Komunikasi dan Kompetensi Terhadap Komitmen Organisasi dengan Pengembangan Karir Sebagai Variabel Moderasi (Studi Kasus pada Akademi Kepolisian). Dharma Ekonomi No. 44

Simatupang, Aprilynn Clarissa, Putu Saroyeni P. (2018). The Effect of Discipline, Motivation and Commitment to Employee Performance. IOSR Journal of Business and Management. Vol. 20, Issue 6. Ver. I.

Sugiyono. (2014). Metode Penelitian Kuantitatif, Kualitatif dan R\&D. Bandung : Alfabeta

Yamali. Fakhrul Rozi. (2017). Pengaruh Kompensasi dan Kompetensi Terhadap Komitmen Organisasi Serta Implikasinya pada Kinerja Tenaga Ahli Perusahaan Jasa Konstruksi di Provinsi Jambi. Jurnal of Economics and Business Vol. 1 No. 1.

Yulianto, Wahyu. (2017). Pengaruh Motivasi, Kepemimpinan, Kompetensi dan Pelatihan Terhaap Kinerja Pegawai dengan Kepuasan Kerja Sebagai Variabel Mediasi (Studi pada Balai Pendidikan dan Pelatihan Aparatur Sukamandi). Tesis. Institut Pertanian Bogor. Bogor.

Wilson.(2012). "Manajemen Sumber Daya Manusia". Erlangga. Jakarta. 